\title{
Non-steroidal anti-inflammatory drug (NSAID) use and levels of a lipid oxidation marker in plasma and nipple aspirate fluids
}

\author{
Ikuko Kato ${ }^{1}$, Gang Chen ${ }^{2}$, and Zora Djuric ${ }^{3}$ \\ ${ }^{1}$ Karmanos Cancer Institute, Detroit, MI, USA; ${ }^{2}$ College of Medicine, Pennsylvania State University, Hershey, PA, \\ USA; ${ }^{3}$ Department of Family Medicine, University of Michigan, Ann Arbor, MI, USA
}

Key words: 15- $\mathrm{F}_{2 \mathrm{t}}$-isoprostane, 8-isoprostane, nipple aspirate fluids, non-steroidal anti-inflammatory drugs, oxidative stress

\begin{abstract}
Summary
Non-steroidal anti-inflammatory drugs (NSAIDs) are thought to reduce cancer risk by inhibiting cyclo-oxygenases, resulting in deceased formation of inflammatory mediators and oxidative stress. We examined whether the level of one oxidative stress marker, $15-\mathrm{F}_{2 \mathrm{t}}$-isoprostane, was affected by NSAID use in plasma and breast nipple aspirate fluids (NAF) of pre-menopausal women who were participating in a dietary intervention trial $(n=121)$. Baseline levels of $15-\mathrm{F}_{2 \mathrm{t}}$-isoprostane were lower in NSAID users than non-users in both NAF and plasma, although the differences did not persist after intervention. Over the duration of the study, information on NSAID use was collected five times, and average $15-\mathrm{F}_{2 \mathrm{t}}$-isoprostane levels in both NAF and plasma exhibited a statistically significant trend for decreases with increased frequency of NSAID use. These results indicate that NSAID use can result in lower levels of $15-\mathrm{F}_{2 \mathrm{t}}$-isoprostane, which may have implications for the effects of NSAID use on breast cancer risk.
\end{abstract}

\section{Introduction}

Non-steroidal anti-inflammatory drugs (NSAIDs) use has been associated with decreased breast cancer risk in many but not all studies. A review of 14 studies in 2001 indicated that NSAID use might be associated with a relative risk for beast cancer of 0.82 [1]. Subsequent studies have either failed to find protective effects or in contrast have found protective effects that were dosedependent [2-8]. NSAIDS also have been suggested to be useful in treatment of breast cancer [9], warranting further research on the effects of NSAIDS on the breast.

NSAIDs are thought to exert their cancer-preventive effects via inhibition of cyclo-oxygenase (COX) enzymes, but NSAIDs also can decrease formation of lipid peroxidation products. Several non-enzymatically formed arachidonate products were shown to be inhibitable by $\mathrm{COX}$ inhibitors in rats [10]. $\mathrm{F}_{2}$-isoprostanes are formed by non-enzymatic oxidation of arachidonylcontaining phospholipids, and they have been suggested to be a marker for the assessment of endogenous oxidative stress levels $[11,12]$. In humans, $15-\mathrm{F}_{2 \mathrm{t}}$-isoprostane formation was shown to be decreased by COX-2 inhibitors, although to a more modest extent than other prostaglandins [13-15]. We previously reported that $15-\mathrm{F}_{2 \mathrm{t}}$-isoprostane are present in very high levels in breast nipple aspirate fluids (NAF) [16,17], and this may be important since lipid oxidation in the breast has been shown to be associated with breast cancer risk [18-20]. In this report, we therefore examined whether NSAID use was associated with decreased $15-\mathrm{F}_{2 \mathrm{t}}$-isoprostane levels in both NAF and plasma.

\section{Methods}

The study subjects were 121 healthy premenopausal (ages 21-50 years) non-smoking women with family history of breast cancer who participated in the Nutrition and Breast Health Study, a randomized intervention trial of low fat and high vegetable/fruits diets over a oneyear period [21]. The study was approved by the Human Investigation Committee of Wayne State University

In this study, fasting venous blood specimens were obtained at months $0,3,6$ and 12 and NAF were collected at 0,6 and 12 months as described [21,22]. Approximately $60 \%$ of the participants were able to provide NAF specimens. At baseline and every 3 months thereafter (5 times over 12 months), dietary intake was assessed by four day food records, body weight was measured using a Health-o-Meter Professional Beam Scale, medication use, activity patterns and health in the 2-week period prior to the visit were recorded on a questionnaire. Average daily energy expenditure values in metabolic equivalents (MET) were then calculated based on subject body weight, time spent on each activity 
and published MET values for each activity [23]). Total $15-\mathrm{F}_{2 \mathrm{t}}$-isoprostane levels in plasma were measured by a kit from Cayman Chemical Co. (Ann Arbor, MI) using a modified Sep-Pak procedure [22,24].

Analysis of covariance [25] was used to calculate and compare the covariate-adjusted mean $15-\mathrm{F}_{2 \mathrm{t}}$-isoprostane concentrations in plasma and NAF by NSAID use. To examine a potential dose-response relationship, we computed the number of visits at which NSIAD use was reported as an indicator for regularity or frequency of NSAID use during the study period. Then, covariateadjusted mean $15-\mathrm{F}_{2 \mathrm{t}}$-isoprostane concentrations in plasma and NAF were calculated according to the cumulative number of visits with NSAID use. In addition, multiple regression analysis was used to assess the linear relationship between plasma and NAF $15-\mathrm{F}_{2 \mathrm{t}}$-isoprostane concentrations and the cumulative number of times of NSIAD use with adjustment for other covariates. In these analyses means of repeated measurements from all visits were used for a given individual for all variables except for the cumulative number of visits with NSAID use. Number of vegetable/fruit servings per day, total fat intake (gram/day) and body mass index (weight $(\mathrm{kg}) /$ height $\left.(\mathrm{m})^{2}\right)$ were included as covariates in these analyses since they were major components of the intervention and since they were marginally associated with plasma and/or NAF 15- $\mathrm{F}_{2 \mathrm{t}}$-isoprostane levels [24]. Age was not included because there were no associations within the limited age range of our study population. Plasma and NAF $15-\mathrm{F}_{2 \mathrm{t}^{-}}$ isoprostane concentrations as well as continuous independent variables were log-transformed $(\ln )$ before multivariate analysis.

\section{Results and discussion}

Users and non-users of NSAIDs did not differ significantly by age, body mass index, activity levels in METs, fat intake, supplement use, race, smoking history, or history of breast-feeding, except for the prevalence of respiratory allergies which was higher in single time users $(p=0.009)$. In NSAID non-users, covariate adjusted mean levels of $15-\mathrm{F}_{2 \mathrm{t}}$-isoprostane tended to decrease with time on study in both plasma and NAF

Table 1. 15- $\mathrm{F}_{2 \mathrm{t}}$-isoprostane levels in plasma and nipple aspirate fluid (NAF) by visit and non-steroidal anti-inflammatory drugs (NSAIDs) use

\begin{tabular}{|c|c|c|c|c|c|c|c|c|c|}
\hline \multirow[t]{3}{*}{ Biospecimen } & \multirow[t]{3}{*}{ NSAIDs } & \multicolumn{8}{|c|}{ Months } \\
\hline & & \multicolumn{2}{|l|}{0} & \multicolumn{2}{|l|}{3} & \multicolumn{2}{|l|}{6} & \multicolumn{2}{|l|}{12} \\
\hline & & No. & $\operatorname{Mean}^{\mathrm{a}}(\mathrm{SE})^{\mathrm{b}}$ & No. & $\operatorname{Mean}(\mathrm{SE})$ & No. & Mean(SE) & No. & Mean(SE) \\
\hline \multirow[t]{3}{*}{ Plasma } & No & 78 & $4.80(0.04)$ & 72 & $4.71(0.04)$ & 62 & $4.81(0.05)$ & 66 & $4.70(0.04)$ \\
\hline & Yes & 42 & $4.69(0.06)$ & 29 & $4.68(0.06)$ & 34 & $4.63(0.06)$ & 31 & $4.67(0.07)$ \\
\hline & $p$-value & - & 0.102 & - & 0.615 & - & 0.028 & - & 0.706 \\
\hline \multirow[t]{3}{*}{ NAF } & No & 35 & $10.18(0.21)$ & - & - & 30 & $9.77(0.19)$ & 35 & $9.66(0.18)$ \\
\hline & Yes & 29 & $9.42(0.24)$ & - & - & 22 & $9.79(0.22)$ & 18 & $9.68(0.27)$ \\
\hline & $p$-value & - & 0.020 & - & - & - & 0.946 & - & 0.962 \\
\hline
\end{tabular}

${ }^{\text {a }}$ Units are $\mathrm{pg} / \mathrm{ml}$ for plasma $15-\mathrm{F}_{2 \mathrm{t}}$-isoprostane and $\mathrm{pg} / \mathrm{g}$ for $\mathrm{NAF} 15-\mathrm{F}_{2 \mathrm{t}}$-isoprostane, adjusted for total fat intake/day, number of fruit and vegetable servings/day and body mass index. All variables in the model except NSAID use were log-transformed.

${ }^{\mathrm{b}}$ Standard error (SE).

Table 2. Mean plasma and nipple aspirate fluid (NAF) 15- $\mathrm{F}_{2 \mathrm{t}}$-isoprostane levels over 12 months of study by reported number of occurrences of non-steroidal anti-inflammatory drugs (NSAIDs) use

\begin{tabular}{|c|c|c|c|c|}
\hline \multirow[t]{3}{*}{ No. of occurrence of NSAIDs use } & \multicolumn{4}{|c|}{ Biospecimen } \\
\hline & \multicolumn{2}{|c|}{ Plasma } & \multicolumn{2}{|c|}{ NAF } \\
\hline & No. & $\operatorname{Mean}^{\mathrm{a}}(\mathrm{SE})^{\mathrm{b}}$ & No. & Mean (SE) \\
\hline 0 & 51 & $4.80(0.04)$ & 20 & $10.17(0.21)$ \\
\hline 1 & 22 & $4.78(0.06)$ & 13 & $9.68(0.25)$ \\
\hline 2 & 17 & $4.69(0.07)$ & 13 & $9.37(0.26)$ \\
\hline 3 & 14 & $4.72(0.08)$ & 7 & $9.42(0.38)$ \\
\hline 4 & 12 & $4.54(0.08)$ & 7 & $9.49(0.37)$ \\
\hline 5 & 4 & $4.68(0.15)$ & 4 & $10.01(0.50)$ \\
\hline$p$-values for liner trend & - & 0.013 & - & 0.033 \\
\hline
\end{tabular}

${ }^{\text {a }}$ Units are $\mathrm{pg} / \mathrm{ml}$ for plasma $15-\mathrm{F}_{2 \mathrm{t}}$-isoprostane and $\mathrm{pg} / \mathrm{g}$ for $\mathrm{NAF} 15-\mathrm{F}_{2 \mathrm{t}}$-isoprostane, adjusted for total fat intake/day, number of fruit and vegetable servings/day and body mass index. All variables in the model except NSAID use were log-transformed.

${ }^{b}$ Standard error (SE). 
(Table 1). Since $75 \%$ of the women were randomized to intervention diets, this suggests that intervention effects might be stronger in NSAID non-users. Levels in NSAID users were lower than that in NSAID users at baseline, and this was significant in NAF. At later time points, the $15-\mathrm{F}_{2 \mathrm{t}}$-isoprostane levels in NAF were very similar in NSAID users and non-users. This was partly due to 24 subjects who dropped out during intervention period. In plasma the lower levels in NSAID users persisted up to 6 months, indicating that levels in plasma do not necessarily predict levels in NAF (Table 1).

The impact of frequency of NSAID use was examined over 12 months of study, and average $15-\mathrm{F}_{2 \mathrm{t}}$-isoprostane levels decreased with frequency of NSAID use reported at each of the five study visits (Table 2). Levels were higher in both plasma and NAF for women who reported NSAID use at all five visits relative to women who reported NSAID use at four visits, but only four women used NSAIDs at all five visits. The trend for increasing occurrence of NSAID use and lower levels of $15-\mathrm{F}_{2 \mathrm{t}}$-isoprostane was statistically significant for both plasma and NAF (Table 2). The decrease in NAF is especially noteworthy since the NAF composition may indicate what breast ductal cells are exposed to. These results indicate that NSAID use can result in lower levels of $15-\mathrm{F}_{2 \mathrm{t}}$-isoprostane in breast NAF, which may one mechanism by which NSAID use can decrease breast cancer risk.

\section{Acknowledgements}

We thank all the women who participated in the Nutrition and Breast Health Study. This study was supported by the U.S. National Cancer Institute through research grants U01CA77297 to Z. Djuric and R01CA93817 to I. Kato. Chandice Covington, RN, $\mathrm{PhD}$ helped design the nipple aspiration procedure and device that was used in this study.

\section{References}

1. Khuder SA, Mutgi AB: Breast cancer and NSAID use: a metaanalysis. Br J Cancer 84: 1188-1192, 2001

2. Jacobs EJ, Thun MJ, Connell CJ, Rodriguez C, Henley SJ, Feigelson HS, Patel AV, Flanders WD, Calle EE: Aspirin and other nonsteroidal anti-inflammatory drugs and breast cancer incidence in a large U.S. cohort. Cancer Epidemiol Biomarkers Prev 14: 261-264, 2005

3. Terry MB, Gammon MD, Zhang FF, Tawfik H, Teitelbaum SL, Britton JA, Subbaramaiah K, Dannenberg AJ, Neugut AI: Association of frequency and duration of aspirin use and hormone receptor status with breast cancer risk. JAMA 291: 2433-2440, 2004

4. Cook NR, Lee IM, Gaziano JM, Gordon D, Ridker PM, Manson $\mathrm{JE}$, Hennekens $\mathrm{CH}$, Buring JE: Low-dose aspirin in the primary prevention of cancer: the Women's Health Study: a randomized controlled trial. JAMA 294: 47-55, 2005
5. Garcia Rodriguez LA, Gonzalez-Perez A: Risk of breast cancer among users of aspirin and other anti-inflammatory drugs. Br $\mathbf{J}$ Cancer 91: 525-529, 2004

6. Swede H, Mirand AL, Menezes RJ, Moysich KB: Association of regular aspirin use and breast cancer risk. Oncology 68: 40-47, 2005

7. Johnson TW, Anderson KE, Lazovich D, Folsom AR: Association of aspirin and nonsteroidal anti-inflammatory drug use with breast cancer. Cancer Epidemiol Biomarkers Prev 11: 1586-1591, 2002

8. Zhang Y, Coogan PF, Palmer JR, Strom BL, Rosenberg L: Use of nonsteroidal anti-inflammatory drugs and risk of breast cancer: the Case-Control Surveillance Study revisited. Am J Epidemiol 162: 165-170, 2005

9. Bundred NJ, Barnes NL: Potential use of COX-2-aromatase inhibitor combinations in breast cancer. Br J Cancer 93(Suppl 1): S10-15, 2005

10. Kadiiska MB, Gladen BC, Baird DD, Graham LB, Parker CE, Ames BN, Basu S, Fitzgerald GA, Lawson JA, Marnett LJ, et al.: Biomarkers of oxidative stress study III. Effects of the nonsteroidal anti-inflammatory agents indomethacin and meclofenamic acid on measurements of oxidative products of lipids in $\mathrm{CCl} 4$ poisoning. Free Radic Biol Med 38: 711-718, 2005

11. Morrow JD, Roberts LJ, 2nd: Mass spectrometric quantification of F2-isoprostanes in biological fluids and tissues as measure of oxidant stress. Methods Enzymol 300: 3-12, 1999

12. Proudfoot J, Barden A, Mori TA, Burke V, Croft KD, Beilin LJ, Puddey IB: Measurement of urinary F(2)-isoprostanes as markers of in vivo lipid peroxidation-A comparison of enzyme immunoassay with gas chromatography/mass spectrometry. Anal Biochem 272: 209-215, 1999

13. Klein T, Reutter F, Schweer H, Seyberth HW, Nusing RM: Generation of the isoprostane 8-epi-prostaglandin F2alpha in vitro and in vivo via the cyclooxygenases. J Pharmacol Exp Ther 282: 1658-1665, 1997

14. Patrignani P: Aspirin insensitive eicosanoid biosynthesis in cardiovascular disease. Thromb Res 110: 281-286, 2003

15. Schweer H, Watzer B, Seyberth HW, Nusing RM: Improved quantification of 8-epi-prostaglandin F2 alpha and F2-isoprostanes by gas chromatography/triple-stage quadrupole mass spectrometry: partial cyclooxygenase-dependent formation of 8-epi-prostaglandin F2 alpha in humans. J Mass Spectrom 32: 1362-1370, 1997

16. Chen G, Djuric Z: Detection of 2,6-cyclolycopene-1,5-diol in breast nipple aspirate fluids and plasma: a potential marker of oxidative stress. Cancer Epidemiol Biomarkers Prev 11: 1592-1596, 2002

17. Chen G, Heilbrun L, Venkatranamoorthy R, Djuric Z: Different factors affect changes in 8-isoprostane levels in plasma and breast nipple aspirate fluids during dietary intervention. Proc Am Assoc Cancer Res 43: 1340, 2004

18. Petrakis NL: Studies on the epidemiology and natural history of benign breast disease and breast cancer using nipple aspirate fluid. Cancer Epidemiol Biomarkers Prev 2: 3-10, 1993

19. Gruenke LD, Wrensch MR, Petrakis NL, Miike R, Ernster VL, Craig JC: Breast fluid cholesterol and cholesterol epoxides: relationship to breast cancer risk factors and other characteristics. Cancer Res 47: 5483-5487, 1987

20. Wrensch MR, Petrakis NL, King EB, Miike R, Mason L, Chew KL, Lee MM, Ernster VL, Hilton JF, Schweitzer R, et al.: Breast cancer incidence in women with abnormal cytology in nipple aspirates of breast fluid. Am J Epidemiol 135: 130-141, 1992

21. Djuric Z, Poore KM, Depper JB, Uhley VE, Lababidi S, Covington C, Klurfeld DM, Simon MS, Kucuk O, Heilbrun LK: Methods to increase fruit and vegetable intake with and without a decrease in fat intake: compliance and effects on body weight in the Nutrition and Breast Health Study. Nutr Cancer 43: 141-151, 2002 
22. Djuric Z, Visscher DW, Heilbrun LK, Chen G, Atkins M, Covington CY: Influence of lactation history on breast nipple aspirate fluid yields and fluid composition. Breast J 11: 92-99, 2005

23. Ainsworth BE, Haskell WL, Leon AS, Jacobs DR, Jr., Montoye HJ, Sallis JF, Paffenbarger RS, Jr.: Compendium of physical activities: classification of energy costs of human physical activities. Med Sci Sport Exer 25: 71-80, 1993

24. Chen G, Heilbrun LK, Venkatramanamoorthy R, Maranci V, Redd JN, Klurfeld DM, Djuric Z: Effects of low-fat and/or high- fruit-and-vegetable diets on plasma levels of 8-isoprostane-F2alpha in the Nutrition and Breast Health study. Nutr Cancer 50: 155-160, 2004

25. Freund R, Little R: Statistical Analysis System (SAS) for Linear Models. SAS Institute, Inc, Cary, NC, 1981

Address for offprints and correspondence: Ikuko Kato, Karmanos Cancer Institute, 110 E. Warren, Detroit, MI, 48201, USA; Tel.: 313833-0715; Fax: 313-831-7806; E-mail: katoi@med.wayne.edu 